\title{
Pendampingan Penggunaan Media Pembelajaran Dalam Jaringan Untuk Meningkatkan Keterampilan Berfikir Kreatif Guru Di UPT SPF SDN 101877 Tanjung Morawa
}

\author{
Imelda Free Unita Manurung ${ }^{1}$, Laurensia Perangin Angin ${ }^{2}$, Suyit \\ Ratno $^{3}$ \\ 1,2,3 Prodi PGSD, Universitas Negeri Medan \\ J1. Willem Iskandar Medan, Sumatera Utara, Indonesia \\ E-mail : imeldafum@gmail.com
}

\begin{abstract}
Abstrak. Mitra PKM yang akan dilaksanakan adalah guru di UPT SPF SDN 101877 Tanjung Morawa. Program pengabdian ini bertujuan untuk melakukan pendampingan kepada guru mengenai pembuatan dan penggunaan media pembelajaran dalam jaringan. Hal ini dilakukan berdasarkan analisis, mulai dari pembelajaran semester sebelumnya dimana pandemi COVID-19 menyerang negara, pembelajaran tidak berlangsung secara efektif dikarenakan kurangnya kesiapan guru dalam melakukan pembelajaran dalam jaringan. Sehingga sebahagian besar anak tidak melakukan pembelajaran dengan efektif. Penyebabnya adalah minimnya sumber dan referensi pendukung yang dapat digunakan guru sebagai media dalam pembelajaran daring. Hal ini menjadi permasalahan serius yang perlu dicarikan solusi sehingga anak di UPT SPF SDN 101877 Tanjung Morawa dapat melakukan pembelajaran dengan efektif. Solusi yang akan dilakukan untuk mengatasi permasalahan mitra antara lain: (1) Sosialisasi dan pendampingan media pembelajaran, (2) pendampingan pembuatan media pembelajaran, (3) pendampingan penggunaan media pembelajaran, (4) monitoring dan evaluasi, dan (5) tindak lanjut. Metode pelaksanaan program pengabdian dilakukan melalui beberapa tahap, antara lain: (1) persiapan, (2) pelaksanaan, (3) monitoring dan evaluasi, dan (4)tindak lanjut. Dengan metode yang digunakan, diharapkan mampu meningkatkan kesiapan guru dalam melakukan pembelajaran dalam jaringan dalam mengantisipasi pembelajaran yang masih bersifat online akibat pandemi COVID-19 di Indonesia, khususnya di UPT SPF SDN 101877 Tanjung Morawa.
\end{abstract}

Kata Kunci: media pembelajaran, keterampilan berfikir kreatif

\section{PENDAHULUAN}

Pandemi COVID-19 yang sedang melanda negara Indonesia menyebabkan terhambatnya proses pembelajaran yang seharusnya dapat dilaksanakan secara tatap muka. Secara keseluruhan kota/kabupaten di Indonesia terdampak pandemi ini, salah satunya di kabupaten Deli Serdang. Berdasarkan data yang diperoleh dari https://covid19.deliserdangkab.go.id/, jumlah masyarakat yang terinfeksi sebanyak 3042 orang, sembuh 2426, dan meninggal sebanyak 159 orang. Informasi tersebut menunjukkan masih sangat tingginya jumlah masyarakat yang terinfeksi virus COVID19, sehingga pemerintah daerah memutuskan dalam tahun ajaran 2020/2021 semester genap, pembelajaran masih bersifat dalam jaringan. Pelaksanaan pembelajaran online pada tingkatan Sekolah Dasar bukan hal yang mudah, observasi di lapangan menunjukkan hampir rata-rata anak di SD tidak melakukan pembelajaran dengan efektif, 
ketidaktersediaan media pembelajaran yang digunakan dalam jaringan menjadi salah satu penyebabnya. Media merupakan bagian terpenting dalam pembelajaran, salah satu yang menjadi tolak ukur keberhasilan dalam proses pembelajaran adalah penerapan media pembelajaran.

Observasi awal dilakukan di salah satu sekolah yang berada di Kabupaten Deli Serdang. Berdasarkan hasil wawancara dengan Kepala Sekolah, Ibu Rizki Aulia Elissa, S.Pd., M.Pd. pada tanggal 05 Maret 2021 dijelaskan beberapa hal yang menjadi kendala di dalam proses pembelajaran secara daring, antara lain: (1) Banyaknya siswa yang tidak memiliki perangkat online, (2) minimnya pemahaman guru mengenai media pembelajaran online, (3) minimnya pemahaman guru tentang penggunaan teknologi, (4) kurangnya kesiapan guru dalam melakukan pembelajaran online, (5) minimnya sumber atau referensi yang mudah dipahami guru tentang cara pembuatan media online, dan (6) kurangnya pemahaman guru tentang penggunaan media pembelajaran secara online di UPT SPF SDN 101877 Tanjung Morawa.

Secara sederhana, gambaran sederhana UPT SPF SDN 101877 Tanjung Morawa dapat dilihat pada Gambar 1.1 berikut.
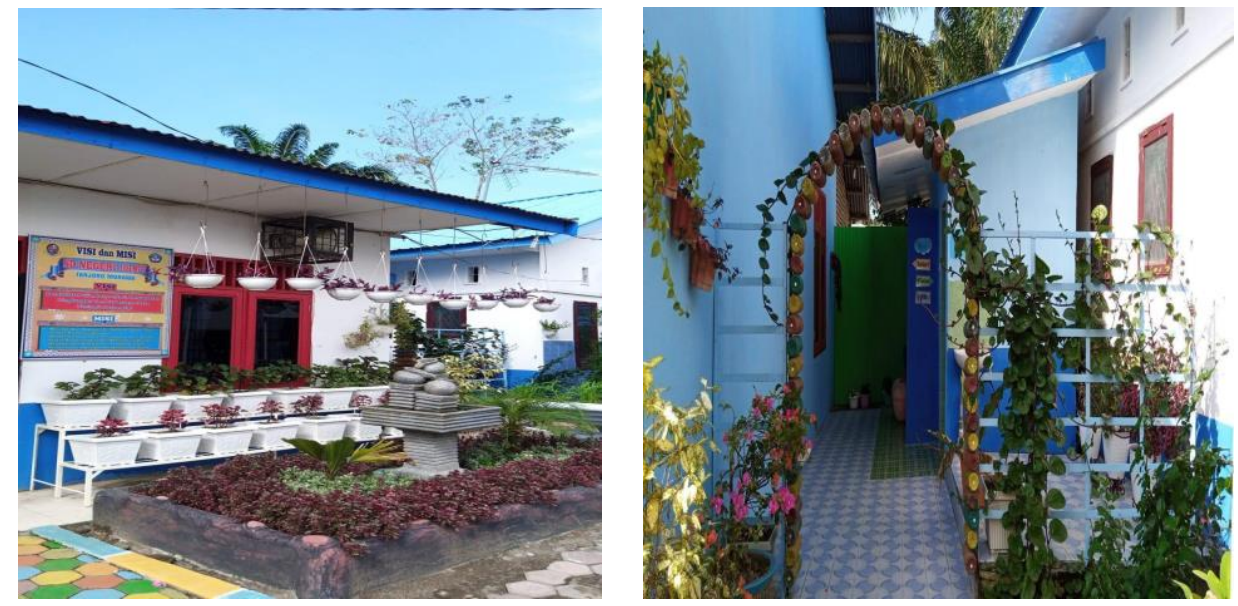

Gambar 1. Lingkungan UPT SPF SDN 101877 Tanjung Morawa

\section{METODE}

Metode yang dilakukan dalam penelitian ini adalah dengan melakukan upaya pendampingan penggunaan media pembelajaran dalam jaringan untuk meningkatkan keterampilan berfikir kreatif guru di UPT SPF SDN 101877 Tanjung Morawa dilakukan melalui kerja sama dengan guru untuk meningkatkan pembelajaran dalam jaringan di masa pandemi COVID-19. Metode pelaksanaan kegiatan dikelompokkan ke dalam beberapa tahapan, di antaranya: (1) persiapan, (2) pelaksanaan, (3) monitoring dan evaluasi, dan (4) tindak lanjut. Metode yang digunakan dalam pengabdian ini antara lain: sosialisasi, pendampingan, simulasi, wawancara, catatan lapangan, observasi, dan kerjasama. Setiap metode diaplikasikan berdasarkan tujuan kegiatan yang ingin dicapai. Untuk lebih jelasnya, dapat dilihat pada tabel berikut. 
Tabel 1. Metode Pendekatan Pelaksanaan Kegiatan

\begin{tabular}{|c|c|c|c|}
\hline No & Kegiatan & Jenis Luaran & Metode Pendekatan \\
\hline 1. & $\begin{array}{l}\text { Sosialisasi dan } \\
\text { pendampingan tentang } \\
\text { media pembelajaran }\end{array}$ & Buku Panduan & $\begin{array}{l}\text { Pelatihan, observasi, } \\
\text { catatan lapangan, dan kerja } \\
\text { Sama }\end{array}$ \\
\hline 2. & $\begin{array}{l}\text { Pendampingan } \\
\text { pembuatan } \\
\text { media pembelajaran }\end{array}$ & Media Pembelajaran & $\begin{array}{l}\text { Pelatihan, simulasi, } \\
\text { observasi, dan observasi }\end{array}$ \\
\hline 3. & $\begin{array}{l}\text { Penggunaan media } \\
\text { pembelajaran }\end{array}$ & Buku Panduan & $\begin{array}{l}\text { Simulasi, wawancara, dan } \\
\text { Kerjasama }\end{array}$ \\
\hline
\end{tabular}

\section{HASIL DAN DISKUSI}

Berdasarkan upaya yang telah dilakukan dalam kegiatan pendampingan penggunaan media pembelajaran dalam jaringan untuk meningkatkan keterampilan berfikir kreatif guru di UPT SPF SDN 101877 Tanjung Morawa yang dihadiri oleh kepala sekolah dan guru guru di UPT SPF SDN 101877 Tanjung Morawa sebanyak 20 orang diperoleh adanya ketertarikan akan pemaparan yang disampaikan oleh narasumber.

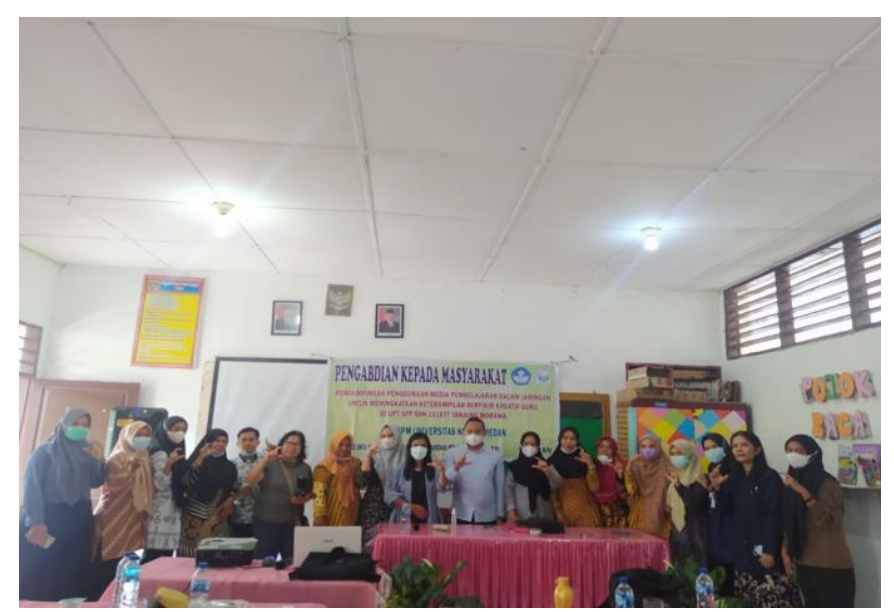

Gambar 2. Peserta Pendampingan Media Pembelajaran

Adapun hasil yang diperoleh dari kegiatan pendampingan yang dilakukan pada setiap tahapannya antara lain:

1. Pada tahap persiapan, dilakukan beberapa kegiatan antara lain:

a. Observasi awal yang bertujuan untuk memperoleh profil mitra.

b. Kesepakatan masalah yang dihadapi mitra bertujuan untuk menentukan permasalahan prioritas mitra yang perlu diberikan pendampingan.

c. Kesepakatan solusi terhadap permasalahan yang dihadapi yang bertujuan untuk mendiskusikan metode atau bentuk kegiatan dalam mencarikan solusi dari permasalahan.

2. Kegiatan yang akan dilakukan pada tahap pelaksanaan antara lain:

a. Sosialisasi dan pendampingan tentang media pembelajaran dalam jaringan 
Adapun tahapan kegiatan yang dilakukan yaitu dengan memaparkan mengenai media pembelajaran secara daring yang dapat digunakan oleh guru dalam pembelajaran di Sekolah Dasar khususnya di masa pandemi.

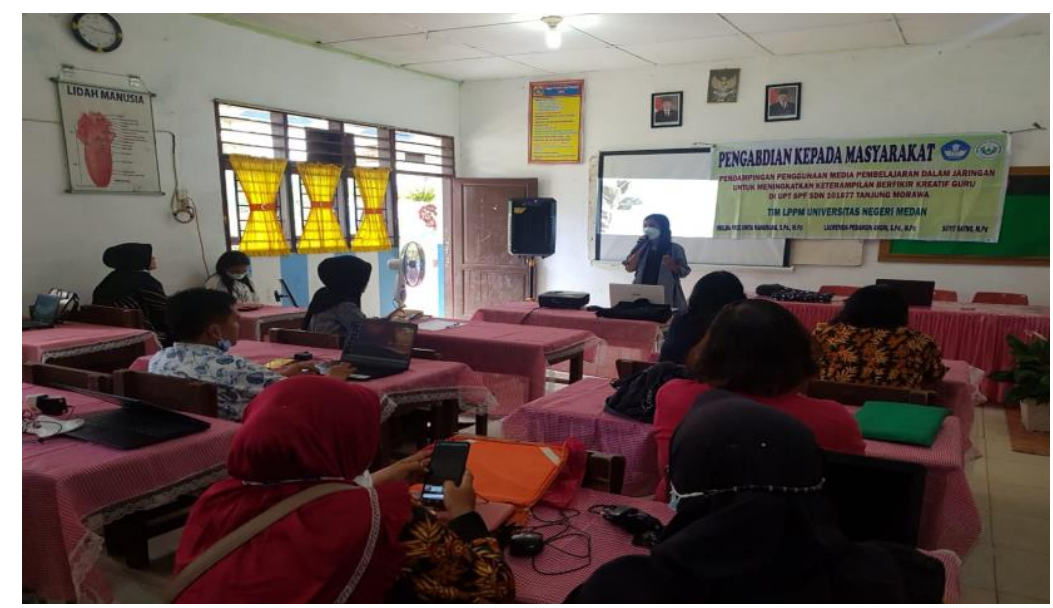

Gambar 3. Pemaparan Media Pembelajaran Secara Online

b. Pendampingan pembuatan media pembelajaran dalam jaringan

Selanjutnya dilakukan pendampingan penggunaan media pembelajaran, dalam hal ini narasumber menerapkan secara langsung salah satu contoh media pembelajaran yaitu powtoon kepada peserta. Antusias dan semangat peserta dalam menerapkan media sangatlah luar biasa dalam kegiatan ini.

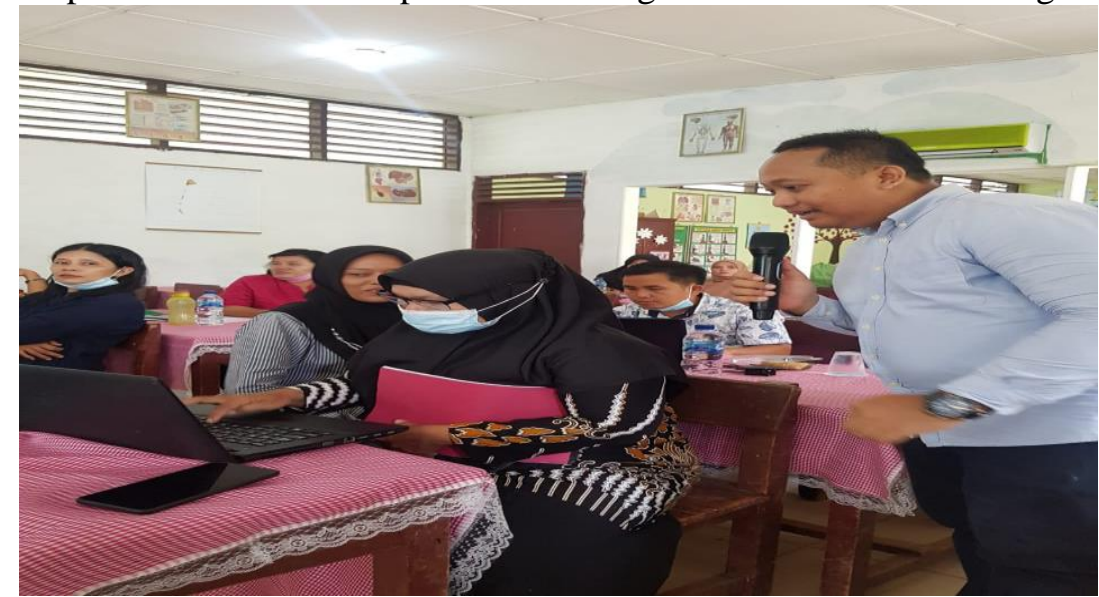

Gambar 4. Pendampingan Media Pembelajaran Secara Online

c. Selanjutnya tahapan evaluasi. Beberapa kegiatan yang akan dilakukan pada tahap monitoring dan evaluasi antara lain:

1) Evaluasi proses yang bertujuan untuk mengukur keberhasilan program terutama dalam hal peningkatan pemahaman dan keterampilan peserta dalam pemanfaatan media pembelajaran.

2) Evaluasi hasil yang bertujuan untuk mengukur tingkat keberhasilan program pendampingan dan sosialisasi.

Dari pelaksanaan kegiatan pendampingan yang telah dilakukan diperoleh data melalui angket dengan indikator keterampilan berfikir kreatif sebagai berikut yaitu fluency, flexibility, originality, dan elaboration. 
Tabel 2. Hasil Angket Kegiatan Pendampingan

\begin{tabular}{|c|c|c|}
\hline No & Indikator & Hasil \\
\hline 1 & fluency & $\begin{array}{l}80 \% \text { peserta mampu untuk memberikan ide-ide } \\
\text { kreatif mengenai media powtoon yang disajikan, } \\
20 \% \text { peserta hanya melihat ide yang disampaikan } \\
\text { peserta lain }\end{array}$ \\
\hline 2 & flexibility & $\begin{array}{l}80 \% \text { peserta merasa media pembelajaran yang } \\
\text { dipaparkan fleksibel jika digunakan untuk anak di } \\
\text { Sekolah Dasar, 20\% peserta menganggap } \\
\text { penggunaan media kurang sesuai untuk anak pada } \\
\text { tingkatan Sekolah Dasar yang belum memiliki } \\
\text { fasilitas online yang memadai }\end{array}$ \\
\hline 3 & originality & $\begin{array}{l}85 \% \text { produk yang dirancang peserta adalah hasil } \\
\text { karya sendiri, } 15 \% \text { ada yang hanya melihat produk } \\
\text { orang lain tanpa membuar karyanya. }\end{array}$ \\
\hline 4 & elaboration & $\begin{array}{l}75 \% \text { kegiatan elaborasi dapat berjalan dengan baik } \\
\text { meskipun sekitar } 15 \% \text { peserta lebih cenderung } \\
\text { mengamati }\end{array}$ \\
\hline
\end{tabular}

Berdasarkan tabel yang dijelakan diatas, penyebaran angket kepada 20 peserta menyatakan secara umum bahwa penggunaan media pembelajaran secara online efektif digunakan pada siswa di Sekolah Dasar, hanya saja proses pembuatan media yang membutuhkan cukup waktu sehingga bisa diterapkan dalam pembelajaran. Adapun kesulitan yang dialami dalam kegiatan ini dapat teratasi berkat adanya kolaborasi dan pendampingan yang luar biasa dari narasumber.

4. Kegiatan yang selanjutnya nantinya akan melakukan tindak lanjut antara lain:

a. Menjadikan UPT SPF SDN 101877 Tanjung Morawa menjadi sekolah binaan LPPM UNIMED berkelanjutan.

b. Melaksanakan Program pengabdian yang sama pada skala yang lebih luas, yaitu pada desa, kecamatan, dan kabupaten lain di Sumatera Utara.

\section{KESIMPULAN}

Berdasarkan kegiatan pendampingan penggunaan media pembelajaran online yang telah dilakukan diperoleh kesimpulan dapat meningkatkan keterampilan berfikir kreatif peserta khususnya guru-guru di sekolah dasar.

\section{DAFTAR RUJUKAN}

Arsyad, Azhar. 2006. Media Pembelajaran. Jakarta: PT.Rajagrafindo Persada.

Sakat, Asmadi. 2012. Educational Technology Media Method in Teaching and Learning Progress. American Research Library.

Iwan Falahudin. 2014. Pemanfaatan Media dalam Pembelajaran. Jurnal Lingkar Widyaiswara

Rudi Susilana dan Cepi Riyana. 2009. Media Pembelajaran (Hakikat, Pengembangan, Pemanfaatan dan Penilaian). Bandung: CV. Wacana Prima 